\title{
The International Geographical Union
}

Author(s): A. R. H.

Source: The Geographical Journal, Vol. 60, No. 4 (Oct., 1922), pp. 291-294

Published by: geographicalj

Stable URL: http://www.jstor.org/stable/1781315

Accessed: 26-06-2016 02:21 UTC

\section{Your use of the JSTOR archive indicates your acceptance of the Terms \& Conditions of Use, available at}

http://about.jstor.org/terms

JSTOR is a not-for-profit service that helps scholars, researchers, and students discover, use, and build upon a wide range of content in a trusted digital archive. We use information technology and tools to increase productivity and facilitate new forms of scholarship. For more information about JSTOR, please contact support@jstor.org.

The Royal Geographical Society (with the Institute of British Geographers), Wiley are collaborating with JSTOR to digitize, preserve and extend access to The Geographical Journal 
hand is doing better than was expected, and he may lose only one fingertip. Dr. Wakefield will be home before the end of September, and General Bruce early in October. Captain Noel is expected in London the day before the joint meeting at the Central Hall on October I6, at which all the members of the expedition who went out from England will be present except perhaps Mr. Somervell.

The greater part of the collections have now been received. About 400 specimens of pressed flowers have been sent to Kew for identification, and the roots of two different primulas which it is hoped may have survived the journey. A small collection of insects and reptiles, and a few birds and mammals, are being examined at the Natural History Museum. The geological specimens, after examination by Dr. Heron, are on their way home. We understand that Mr. Somervell has made a large number of sketches, and has also recorded the music of many Tibetan songs. Captain Noel, when he wrote last from Gyantse, had obtained excellent films of Tibetan life and of Lama ceremonial.

General Bruce has reported to the Mount Everest Committee that suitable provision has been made for the families of the seven Nepalese porters unhappily lost in the third attempt. The Commissioner at Darjeeling has very kindly undertaken the monthly payment of the allowances, on behalf of the Committee.

\section{THE INTERNATIONAL GEOGRAPHICAL UNION}

A $\mathrm{T}$ a Conference held in London in October 1918, between representatives of the Academies of Science of the principal Allied Powers, it was resolved that the nations at war with the Central Powers should as soon as possible denounce the conventions governing International Scientific Associations, and should form new scientific associations for international co-operation, with the eventual concurrence of the Neutral Powers. To this end an International Research Council was organized at Brussels in I919 by representatives of the Principal Allied and Associated Powers, and to this Council the neutral nations, Spain, Holland, Sweden, Norway, Denmark, and Switzerland have since adhered.

A principal object of the International Research Council is to promote the formation of International Unions in the different sciences or groups of sciences. When a new Union is proposed, the first step is to form in each country a National Committee for that science, under the auspices of the National Academy of the country. When, therefore, it was proposed by certain French and Belgian delegates to the first General Assembly of the Council that an International Geographical Union should be formed, the Royal Society consulted the Conjoint Board of Scientific Societies, and on its recommendation constituted a National Committee 
for Geography, comprising two representatives of the Royal Society, three of the Royal Geographical Society, one each of the Royal Society of Edinburgh, the Royal Irish Academy, the Royal Scottish Geographical Society, and the Geographical Association, with the Hydrographer of the Navy, the Director-General of the Ordnance Survey, and the President of Section $\mathrm{E}$ of the British Association as ex-officio members.

This Committee, meeting in I92I under the chairmanship of Sir Charles Close, resolved to recommend to the Royal Society that Great Britain should join in the proposed formation of an International Geographical Union, and that delegates to the next meeting of the Research Council should be nominated to this end. Having carefully considered a draft of proposed statutes, following closely those already adopted for the Union of Geodesy and Geophysics, the British National Committee resolved to suggest a simplification by omitting the division into six or more sections, each with its own President, Secretary, and organization. This suggestion was submitted to the French National Committee for consideration.

The second General Assembly of the International Research Council was held in the Palais dẹs Académies at Brussels on July 25-29. Its agenda included the question of the formation of an International Geographical Union: the Royal Society had therefore nominated among the British delegates Sir Charles Close, Colonel H. G. Lyons, and Mr. Hinks. French geographers were very strongly répresented by Prince Bonaparte, General Bourgeois, M. Cordier, M. Lallemand, Colonel Bellot, Professor de Martonne, M. Grandidier, and Colonel Perrier; Belgium by Colonel Seligman, Professor Hegenscheidt, and M. Kraenzel; Italy by General Vacchelli and Professor Magrini ; Japan by Professor Yamasaki and Dr. Nakamura; Spain by General Nuñez Gomez, Professor De Buen, and Señor Mereguor; Portugal by Admiral Nouparth; and Poland by Professor Szajnecha.

A little preliminary discussion during the first two days of the Assembly prepared the way for a very harmonious meeting of the geographical delegates on July 27, with Professor Hegenscheidt in the chair. The Statutes as redrafted by the Presidents of the several National Committees were agreed without dissent. Prince Bonaparte was chosen unanimously the first President of the International Union of Geography, and Sir Charles Close the General Secretary. The formation of the Union and the adopted Statutes were reported to the final meeting of the General Assembly of the Research Council on July 29, and will be submitted for confirmation to the National Academies of the constituent countries, which will be invited to adhere to the new Union.

The Statutes thus submitted for confirmation necessarily conform in principle to those of the International Research Council. The General Assembly of the Union is formed of delegates nominated by the National Committees, which are charged with the study of geographical questions 
in their international relations. A question to be considered by the Union must be submitted in advance by a National Committee. Any member of a National Committee may attend the General Assembly and speak; further, the President may invite scientific men of any adhering country to attend the meetings of the Assembly in a consultative capacity. But on all administrative questions-and these are really the only questions upon which a vote is possible - the vote is cast by countries, and is weighted according to a scale depending on the population of the country. This requires that the voting powers of any country shall be entrusted to one of its delegates-as in the Assemblies of the International Research Council-and the method has the considerable advantage that it will compel each group of national delegates to prepare for the meeting by a preliminary settlement of any internal disagreements, so that at the General Assembly they can support the national vote on a united front.

The Executive Committee of the Union shall, it is proposed, consist of the President, the General Secretary, and not more than six VicePresidents. It was agreed to recommend that General Vacchelli (Italy) should be the First Vice-President, and that three of the remaining five places should be filled by Professor Yamasaki (Japan), General Nuñez Gomez (Spain), and Commandant De Gerlache (Belgium).

The funds of the Union will be derived from the annual contributions of adhering countries on a unit of 500 francs (French currency), and the number of units payable by any country depends on its population, according to the scale adopted by the Research Council, with a maximum of eight units. These funds will be devoted to the expenses of administration, the cost of publications made under the direction of the Union, and ultimately to the cost of special researches undertaken by it. The British Government has placed in the hands of the Royal Society an annual sum for the payment of the national contributions to International Unions.

The General Assemblies of the International Union of Geography will be held every three years. Their principal end will be to promote and co-ordinate researches requiring the co-operation of several countries ; to ensure their scientific discussion and publication; and to organize International Congresses of Geographers.

The International Union of Geography being thus in a fair way to foundation, it is necessary to consider what it may usefully do. The proposed Congresses will presumably coincide with the meetings of the General Assembly: they will serve the excellent purpose of bringing together for mutual acquaintance the geographers of adhering countries; their meetings will provide opportunity for discussion of questions not formally brought before the General Assembly. But it seems that the Assembly will constitute a more formal, a more authoritative, inner body 
representative of the considered opinions of the National Committees, and able to give them effect because it will control funds of some importance. The executive committee will ensure continuity of effort; and the new organization will have much more power of effective work than the old type of International Conference, that was not really representative, and could do little more than promote acquaintance, air opinions, and pass resolutions that bound no one in particular.

In the present condition of the world the cost of international meetings must be reduced to a minimum, and it is particularly desirable that no special expense should fall upon the country that is chosen to be the seat of a General Assembly. It might be well that each International Union should make it clear from the beginning that it does not expect to be entertained; that it would prefer to meet rather informally in a place chosen for interest and convenience, preferably not a capital city where hotels are expensive; that it is prepared to pay from its corporate funds for the hire of the necessary meeting-rooms, say in a smaller University city; and that nothing more is expected of any national or local committee than that it shall assist the delegates to find convenient, modest accommodation, each at his own expense. If this were once thoroughly understood, it would be possible for the International Geographical Union to meet in smaller, less well known, and geographically more interesting places than any which could be expected to invite an Assembly. A. R. H.

\section{DOLOMIEU AND DE SAUSSURE}

Déodat Dolomieu Membre de l'Institut National (I750-180r): Sa correspondance, sa vie aventureuse, sa captivité, ses œuvres. Tomes r, 2. Par A. Lacroix. Librairie Académique Perrin et Cie. Paris, I92 I.

$\mathrm{T}$ $\mathrm{HE}$ biographical material ready for use in recording the lives of the two leading Alpine geologists of the eighteenth century, after lying neglected for a hundred and twenty years, has by a curious coincidence been taken seriously in hand almost simultaneously in this country and in France. Two years ago my volume on de Saussure was published. Twelve months later the Secrétaire perpetuel de l'Académie des Sciences de France has brought out two volumes dealing with de Saussure's attached friend and follower, Dolomieu.

Monsieur Lacroix has not thought fit to weld his abundant material into the form of a biography. He has preferred to furnish brief outlines of his subject's romantic career and scientific activity as an introduction to copious extracts from his journals and his correspondence. His task must have involved much research, since the letters were widely scattered. It has been executed with great thoroughness, and the documents are annotated throughout with the precision we look for in such a quarter. The few printer's slips we have noticed, beyond the list of "errata," are not worth mention.

The life of-to give him his full name-Dieudonné-Sylvain-Guy-Tancrède dit Déodat, de Gratet, de Dolomieu was far from being the tranquil existence 